\title{
Globalization and Transnationalism in Indo-Pakistan Region: A Historical Overview
}

\author{
Prof. Dr. Razia Musarrat \\ Chairperson, Department of Political Science, The Islamia University of Bahawalpur \\ Email: drrazia_mussarat@yahoo.com
}

Samina Noor (Corresponding Author)

Department of Political Science, The Islamia University of Bahawalpur

Email: sameena.noor786@yahoo.com

Received: July 06, 2013 Accepted: August 18, 2013 DOI: 10.5296/jpag.v3i3.4149

\begin{abstract}
South Asia contains twenty two percent of the world, is one of the fastest growing regional economies. Therefore, such global progress has also a dark side, that region also facing some worse kinds of economic, social, and political issues. Globalization also intensifying the transnational activities across the borders, when criminal networks and globalization developed freely crosses borders relations. This research paper focused on the historical impact of globalization and transnationalism on Indo-Pak region of South Asia. Globalization and transnationalism has changed the entire security environment for the traditional enemies in South Asia. This paper also put some light how globalization and transnationalism boots up the cross border security issues of both India and Pakistan. In this research paper we discussed comprehensive historical background of trans-border issues in South Asia particular in India and Pakistan. This paper also discussed the strategic and historical importance of Subcontinent (prior independent) and after partition.
\end{abstract}

Keywords: Globalization, Transnationalism, South Asia, Indo-Pak Region, Cold War 


\section{Introduction}

This research paper focused on the historical impact of Globalization and transnationalism on Indo-Pakistan Region. As the ensuing examination indicates, the potential benefits of the integration of the world in contemporary globalized world mismanaged in the third world countries. The chasm between the included and the excluded created during the decades of exposure to globalization in the South Asia has resulted into worlds, one of the dominated by burgeoning trade, transnational corporation and organizations, modern technologies, high living standard, and with level of source of availability, and the other world which is dominated by low wages, high prices, extreme poverty, deprivation, increased population, and economic deprivation.

Despite the favorable views in academic community about globalization especially its effects on developed and developing countries and despite the strong support of the empirical evidence of the benefits that may developing countries have resulting from their integration with global economy, the criticism against globalization continues unabated.

South Asia contains twenty two percent of the world population and is one of the fastest growing regional economies. Therefore, but such global progress has also a dark side, South Asia also facing some worse kinds of economic, social, and political issues. Globalization is intensifying the transnational activities across the borders, when criminal networks and organizations developed freely cross border relations.

\section{Indo-Pakistan Region}

Indo-Pakistan region has a distinctive geopolitical identity. No doubt, that region has been a piece of important for every superpower from Greeks to Americans. Actually, that region becomes fertile lands for great power games of world politics. This region also has significance importance because it has many connected routes to Africa, rest of Asia, and direct links with Indian Ocean.

From the very first day of the independence, this region has been beset with numerous interrelated domestic and inter-state conflicts owing their origin to a large number of sources. These were rooted in the colonial past as well as the dynamics of postcolonial social-economic and political culture development of the Indo-Pak societies. Intra and interstate conflicts in the region have often been compounded in with the process of the interaction with the outside world. The newly emerging states India and Pakistan made friendly relations with India and China respectively, but those relations based on their foreign Policies. Nevertheless, the Cold War scenario changed the shifted the center of their foreign policies.

During cold war era, the bi-polar world order, characterized the world between two blocs, has

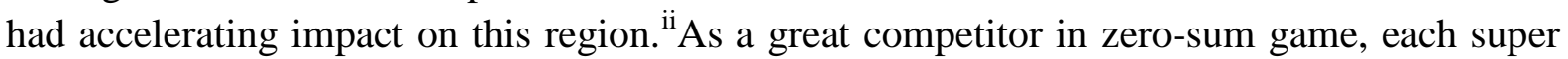
power play great role in the internal conflicts in South Asia. In that environment, the American' interest in South Asia has vary time to time, depending upon the intensity of the issues. The Cold War environment led to a main geopolitical realignment on the South Asia, which left Pakistan most advantageous position. 


\section{Mll Macrothink}

Journal of Public Administration and Governance ISSN 2161-7104 2013, Vol. 3, No. 3

The importance of Indo-Pakistan region increased after the nuclearization of India and Pakistan especially for America. However, the hostility remains constant over Kashmir, and nuclear ability affect each other behavior over that issue. In 1970s, many Jihadi movements were stimulated in response to Soviet Union invasion of Afghanistan, which lead to the terrorism in the region. The region itself is war prone, it bound with territorial and resources disputes. ${ }^{\text {iii }}$ Also, there are many external regional factors on each state' nuclear behavior. Iran, Russia, China, United States, United Arab Emirates, Japan, South Korea are the main external factors that enhanced the potential crises in the region due to nuclear commercial basis. ${ }^{\text {iv }}$ Terrorist groups and non-state actors also destabilized the region and serve as proxies between India and Pakistan.

The Post Cold War era has totally changed the strategic environment of this region. The event of $9 / 11$, the South Asia becomes the central point of the war against terrorism. The affects of war against terrorism on this region was seen in raised terrorist activities and attacks on both India and Pakistan. Pakistan becomes the frontline ally in this war against terrorism with U.S.

Since independence, Indo-Pakistan region remains swamped in a nasty cycle of poverty, economic deprivation, and underdevelopment, low access to job opportunities. Such circumstances made the region a fertile land for intolerance and extremism that leads to conflicts and violence within the societies.

\section{India: An Over View}

India is the seventh largest country by area and second most populous country in the world. She considered the most populous democracy in the world. It has Indian Ocean on the south, Bay of Bengal on southeast, Arabian Sea on the southwest, Pakistan on west, Nepal, China and Bhutan on north east, Bangladesh and Burma on the east. India also shared border with islands of Sri Lanka, Maldives, Thailand, and Indonesia.

With the end of British raj, Indian Subcontinent was left behind with many territorial issues in the shape of the injustice demarcation of the boarders between India and Pakistan. Those partitions directly lead to the border issue with China and Pakistan. Consequently, India had involved herself in several boarder wars like with China in 1962, with Pakistan in 1947, 1965, 1971, and 1999. Partition implanted distrusts the neighbor countries that had formed new boarders with India. We can say that the imperialist attitude and desire to become the leader of this region, India adopted the hostile attitude towards others. India is emerging a possible great power in the Asia. Especially after the Cold War and disintegration of Soviet Union, India prejudice toward becoming the great power in the Asia. In contemporary world, the increasing involvement of India in World affairs preventive it from taking steps to solved their internal problems.

South Asia has comprised multi-ethnic and multi-religious societies. Therefore, it is very hard to find the any ways in which democracy and secular tolerance flourish as a source of stability of the region. However, stable democracy and secure secular is the key the establishment and protection of the human rights in the region. India depicts that these dogmatic ethics can be established and implemented even in an environment increasingly troubled by fundamentalism and ethno-religious conflicts. 
Usually countries overwhelmed by internal conflicts resulting from autocratic rule, civil war, and anarchy. India should be taken as an example, where democracy continuously prevailed in multi-ethnic and multi-religious society, despite the pressure of poverty and destitution.

When India came into exist in post World War II, the world order was bi-polar. The world divided into two blocks on ideological conflict. In those circumstances, it was difficult for India to stay out of the Cold War, but she remained because of its political predisposal. India decided to remain neutral in Cold War ideologically and the principle of self-preservation.

Post Cold War is totally changed the world political system and new world order established on the hegemony of United States. Post Cold War era also transformed the pattern of trade, political economy, and pattern of investment between the nations. ${ }^{\mathrm{V}}$ However, new world order are being established according to the American' liberal ideologies and security requirements. Indian's relations with US during post cold war period much satisfactory. During that period, India eliminated his policy of estrangement.

The 9/11 event developed very close relation between US and South Asia. In War against terrorism in South Asia, India becomes valuable alternative of Pakistan if needed due to her geographical location in South Asia. Indian government overt and covert supports US to attain their objectives in Afghanistan. No doubt, India overwhelmingly dominates the Subcontinent by geographically, size, economy, military, technology and by others means. However, India occupied all geographically transition zones that give little chance to other smaller states to establish them.

\section{Pakistan: An Overview}

Pakistan is situated at the crossroads of three major regions Asia. Pakistan has a unique position in the South Asia. It links with central Asia to the north side i.e. Middle East to the west and the Indian Subcontinent to the east. In South Asia, Pakistan shares a northeastern border with China, and eastern border with India. Iran found the south western and Afghanistan make up the western northern border. Pakistan comprises an area of 796,095 sq.km and consisted on provinces: Punjab, Sindh, Khaiber Pakhtoon khawa (KPK), and Gilgat Baltistan. Pakistan is the seventh most populous country of the world. Pakistani economy is predominantly agriculture, because it is the main source of income.

The creation of Pakistan was most advanced by Mr. Jinnah, who was the prominent leader of the Muslim League. Jinnah provoked that, India dominated two main ethnic groups Muslims and Hindus were not live together in Hindu dominated Subcontinent. The religion not only one reason behind that demand. The Muslim economically, socially, politically, and ethnically separated then Hindus. The Second World War and widespread resistance to British Raj in Subcontinent motivated to British to give independence to their colony in 1947.

Pakistan has adopted federal and parliamentary form of government from her inception. The president as the head of the state and prime minister as the head of government are chooses in the opted system of government. It consisted on bicameral system of legislation. ${ }^{\mathrm{vi}}$ In the federal system of the state, previously central enjoyed maximum autonomy over provinces but eighth amendment gives enormous power to provinces. ${ }^{\text {vii }}$ In Pakistan, military remains the most cohesive nation institution. Since independence, it has oscillated between indirect 
and direct political control in the country.

Pakistan's position in the international level has changes dramatically in the twentieth century during Cold War. During the war, Pakistan achieved international status as a front line ally during the Soviet invasion of Afghanistan. ${ }^{\text {vii }}$ However, during the war, Pakistan gave fully support to the Afghanis against the Soviet domination. No doubt, Pakistan became the way to imposed new American world order on the world.

Pakistan cultivated herself for combating terrorism and insuring peace and stability in the South Asia. ${ }^{\text {ix }}$ America also wanted, Taliban, and Al-Qaeda formally based in Pakistan, did not find safe havens in Pakistan. Pakistan has never been so relevant to the global politics. Its strategic significance has diverse over time that had inferences for Pakistan's role at the international echelon and the foreign policy alternative available to its policy makers. ${ }^{\mathrm{x}}$ However, it is very difficult for Pakistan to stay isolate in the contemporary global system. It is necessary to interact with other states, international and regional organizations in order to keep its national interest and sovereign identity. Pakistan also engaged herself with other countries collectively cope with the global issues like over population, poverty, underdevelopment, energy, drug trafficking and terrorism.

Pakistan also recognizes with the economic and political concerns of the developing countries. Pakistan always used to support to the right of self-determination for the subjugated nations, always condemned apartheid policies.

\section{Globalization in Indian-Subcontinent}

Although the intense focus on the concept of the globalization over the past two decades, many analysts scrutinize that it is myth to assert that globalization is an odd modern phenomenon of the last fifty years. Instead, they agree to fluctuate that the occurrence has had a extensive history, spanning many centuries in the region of Indian-Subcontinent. In Indian-Subcontinent, globalization can be seen as a continuing concept that historically has taken different shapes for their growth. ${ }^{\mathrm{xi}}$

In $300 \mathrm{BC}$, Asian continent had created communicational, migration, and trade links outside the region. Such types of communication, interaction, interconnectedness largely established on global, regional, and local spheres has been a crucial driving force in the world history. ${ }^{\text {xii }}$ Alexander the Great used for peace with Subcontinent's Chandragupta, the Mauryan Emperor at the place of Gerosia in 325BC. This encounter smudged the East connection among overland routes between the Mediterranean, Persia, India, and Central Asia. ${ }^{\text {xiii This }}$ was the earliest documented encounter through which trade, religion, trade, economy, and imperial armies of the West and East began the long journey of global diffusion. The eastward expansion of this interconnectedness and linked dispersion of information and culture is manifested with the arrival of Buddhism to the extent that China in the first century AD with the conversion of the Han dynasty. ${ }^{\text {iv }}$ The Silk Road became important since the first century, when it was militarily confined under the Hans and as such opened up a region previously unfamiliar to Central Asia. ${ }^{\mathrm{xv}}$ Cultural and trade links between two civilization put great impacts on the Asia and China.

The growth of Islam in the course of the western Mediterranean, Central Asia, India, and 
eastwards during 650-850 AD manifest another landmark in the history of globalization in India. $^{\text {xvi }}$ Although Islam brought great cultural, political, social, religious, and economic changes to the people of India. In 1300 AD, the Ottomans Empire established political and commercial connection with Safavids and dynasties in Central Asia and India. This connection established an immense imperial network of integration that led to an enormous development of trade with Europe.

About 1600 to 1800 centuries, due to internationalization of the trade routes, globalization entered into new phase where European seabome empires were created. During these seabome empires, Europeans not only established firstly the system of export in the region of Asia and America and created bank system in those regions mainly controlled by Europeans. ${ }^{\text {xvii }}$ During the period European imperialism, European nations also used their military power to protect their trade companies, which leads to made colonialied the new regions. In $18^{\text {th }}$ century, the British East India Company monopolized the whole Subcontinent for their trade purposes. The company characterizes a very early version of a multinational corporation. In $19^{\text {th }}$ century, the British Empire in Asia changed as a mean of economic imperialism rather than territorial domination. ${ }^{\text {xvii }}$ However, we can say that the globalization entered into its modern phase due to the rise of the nation state and industrialization of the world. ${ }^{\mathrm{xix}}$ In this era of the globalization, colonial territories of Asia and Africa produced raw material for European industry and trade.

After postcolonial era, new actors USA and Japan also became the part of the contemporary globalization. During this era Europe, USA, and Japan established themselves as global economic superpowers and maintained the colonial status of the newly born nation states. Contemporary globalization represents a new world order where the boundaries become visible day by day and people more mobilized one country to another. ${ }^{\mathrm{xx}}$ Contemporary globalization seeks to promote prosperity, peace, technological and economic development everywhere. Some critics take it as a means of exploitation of third world by throwing them into debt, inflation, unemployment, environmental degradation, and so many other fatal issues.

South Asia has always been regarded as more strategically region of the Asia. It territorial, strategically space, and the resources it contains are always important for the rest of the Asia and world. However, the nations of this region facing complex political economic and social challenges whose puts badly effects on both inside and outside their boundaries. ${ }^{x x}$ For instance, South Asia is at significant crossroad for global political security discussion especially during Cold War and War against terrorism. This region also being considered breeding and training grounds for various terrorist organizations.

South Asia fully has recognized newly transnational regime in the 1980s. The influences of globalization reached everywhere of the societies of this region. The effects of globalization and its reaction on the South Asia have not been uniform. However, one group has promoted globalization in South Asia and other has taken it with high range of emotions from a deep sense of abhorment. 


\section{Globalization and Third World: Its Impacts on Indo-Pakistan Region}

The term third world firstly used in period of Cold War to mention those countries that remained separate or non-aligned (not joined capitalism-America, and its allies and communism-Soviet Union and its allies). The first bloc (capitalism) called first world and last (communism) mentioned as second world. After Cold War, this term used everywhere to represent the poor countries of Asia, Africa, and Latin America excluded the non-aligned countries. ${ }^{x i i}$ This division also represented a very concise definition of the categorization of the world into three groups based on social, economic, and political divisions. Third world also divided into poor and poorest.

MacWorld has rather jeopardize the nation state perception, especially so long as the regional economic associations are directly or indirectly falling prey to the developed world and IFIs. ${ }^{\text {xxiii }}$ The implication of globalization sounds interdependence in the best interest of both the haves and haves not. Yet the same idealistic perception of the globalization inevitably curtails the freedom of the choice for the newly independent qualities and their process of policy-making in this world of turmoil.

Prior to WWI, the close interdependence of the states was of as precursor an era of peace between nation's democracy as well as affluence within them. Associating interdependence, peace, democracy, and prosperity is nothing new. ${ }^{\text {xxiv }}$ World War I abridged political sanguinity to a level that remained low almost until the end of Cold War. In 1970s, new optimism embarked on to resurface. Interdependence was over associated with peace, while peace increasingly with democracy. ${ }^{\mathrm{xxv}}$ The latter began to spread astonishingly to Latin America, to Asia and with the collapse of Soviet Union spread over Eastern Europe.

Globalization creates firstly inequality based on economic all over the world. There are $70 \%$ of population only in Africa never been access to computer and internet. We might call it a huge digital division. ${ }^{\mathrm{xxv}}$ This division led to significant division between South and North on economic bases. Language shows another barrier for the poor in the South, since $80 \%$ of the content on the internet is in English. The world's poor also forced to handle a large proportional of the world's highly dangerous e-waste.

A main consequence of inequality is an increase in migration; especially South-to-North and South-to-South migration is very familiar. ${ }^{\text {xxvii }}$ This movement may be the result of push factor such as wars and other political crises, as well as pull factors such as better work and pay. South-to-South migration is likely to increase in the face of stricter controls over migrants are usually poorer and more rural as compared to the South-to-North migrants.

All majority and minorities statuses involve social definitions. Consequently, these statuses tend to differ, with variations in social definitions from one locale to another and over time. ${ }^{\text {xxiii }}$ For example, there is nothing intrinsically characteristic about any racial or ethnic group that distinguishes it from other-these are fluid categories that are socially defined.

Whereas some argue that globalization poses a threat to ethnic identities, they may in fact be shatterproof by confrontation to global pressures towards homogenization of identity. Certainly, globalization and the foundation of the ethnicity may be seen as part of the some modern process. ${ }^{\text {xxix }}$ Greater ethnic diversity within nation-states has increased the likelihood 
of ethnic conflict within their boundaries. Various methods may be adopted to deal with ethnic minorities' in nation-states or other enclosed areas. The most extreme involve genocide.

After decolonization, globalization has had impacts on the both internal and external sovereignty of the Indo- Pak Subcontinent. ${ }^{\mathrm{xx}}$ On one hand, globalization encourages global integration of nation-states and on other hand such integration curtails the assertion of sovereignty of individual states. This is particular pertinent in the sphere of economic activities of the states. However, the autonomy and usefulness of national economic policy have decreased as a direct result of globalization of financial market and financial deregulation.

In South Asia, societies always experienced less tolerance since the past. In relation to the issue of state patronage of religion in the Subcontinent, all states in this research have had diverse and turbulent histories combined with an overarching ethos of general acceptance and tolerance of religious diversity.

Poverty means the dearth of prospect in every aspect of personal life, further aggravated by chronic hunger, unemployment, illiteracy, lack of education facilities, almost non-approach to

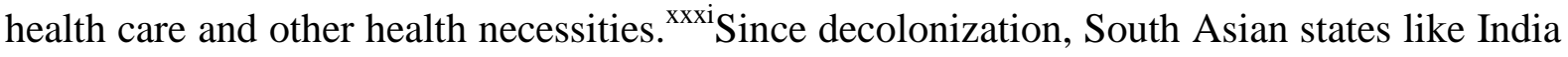
and Pakistan failed to remain to exact social engineering designs that would purge inequalities in terms of resources and land distribution, infrastructure development, capital, education, information would consequently have paved the way for a diverse outcome rather than the conditions of poverty that exist today.

\section{Security Environment of South Asia: Indo-Pakistan Region and its Security Dilemma}

To say that low politics are considered as more in the after math of the cold War is beyond dispute. Many researchers have been undertaken the damages to the environment should be considered as a threat to the national security because it can cause causalities or even kill. ${ }^{\text {xxii }}$ Many researchers has suggested that damage to the earth's ozone layer should be considered to be a security threat because it causes cancer, blindness, and even death. However to say that environmental damages or resources scarcity should now be considered as national security issues raises a host of problem, especially for those who are concerned military strategy. ${ }^{\text {xxxii }}$ Some scholars considered that environmental, global, or transnational issues are national security threats. Resources scarcity or the disorder produced by overpopulation or rapid depopulation may the cause of a war.

Defining some transnational issue as a national security threat also can create a new set of problems. Often military forces are the only units available that posses the logistical capabilities or the able bodies and disciplined work force needed to cope with the aftermath of natural or political disasters. ${ }^{\text {xxxiv }}$ Regardless of circumstances or initial intentions, however, the introduction of military forces risks making things worse by turning a public health crises or police problems into an armed conflict.

Issues that transcend international boundaries often are referred to as common problems. Although some countries can contribute more or less to a specific common problems, efforts to stop the tragedy of the common. Most low politics problems could be classified as 
common issues. Many common problems are probably beyond the reach of strategy, and military infrastructure did little to deplete such common issues.

\section{South Asia Cross Boarder Analysis}

It is essential to identify the threats to security that are required to recognize threats to security among states. These threats are military strategic, political, socio-economic, cultural, and ecological. Military-strategic threats involve familiar concerns over the possibility of armed attacks that can subjugate.

Political threats are typically associated with challenge to the legitimacy and authority of the state. They may be threats posed to national identities by a collapse of the state to integrate sectional, linguistic, ethnic, and sectarian groups, as well as the perils to the survival faced by any political structure. ${ }^{\mathrm{xxv}}$ The stability of those exercising political power or often serves as a measure of success in handling with political threats.

The scales of economic security are likely to be assessed against needs and expectations and are often measured by how well a country realizes resources security through self-sufficiency or greatest self-reliance. ${ }^{\mathrm{xxvi}}$ State actors in South Asia are in particular likely to be judge by how by the further economic growth with equity. Cultural threats to security involve challenges to traditional values and institutions. For South Asia, association have been made with colonialism and, later traced to economic and political dependencies.

Cultural threats may arrive with unavoidable participation in global markets of good and ideas. Nevertheless, these values and behaviors pose threats only when they are resisted. With the resurgence of Islamic militancy in Pakistan and in the advent of Hindus militancy in India, added attention has been given to fending off alien cultures, especially those of the West. ${ }^{\text {xxvii }}$ However, more directly felt are the internal threats represented by the conveyance of traditions and beliefs seeking to impose their values and enforce certain behaviors.

Ecological threats take the form of possible worsening of the environment or exhaustion of natural resources so as to economic future of the state, region, or beyond. The threats from environmental behavior in South Asia has been tardily recognized, the fault lies with the people themselves as well as with lax government policies.

As we have seen, the end of the Cold War brought relative peace and stability to the countries of the South Asia as part of the super powers and China had jockeyed for influence, either directly or through allies, since the beginning of the 1950s. ${ }^{\text {xxxvii }}$ In South Asia, the Soviet withdrawal from Afghanistan in 1990 removed the basis for the tacit alliance among the United States, China, and Pakistan during the 1980s in the support of the afghan resistance to the Soviet Occupation. This new strategic environment led to a major geopolitical shift on the Indian Subcontinent in the early 1990s that left the Islamic Republic of Pakistan in an exceedingly advantageous position: it was relieved of the threats from its long-standing Soviet antagonist. Beyond its previously unstable northern frontier lay an Afghanistan controlled by Islamic militant it had helped to put in power and whose fundamentalist faith resembled that of the state that had proudly named its capital Islamabad and subjected its citizens to Islamic religious law(Sharia). 
Further to the north lay newly independent successor states of Soviet Central Asia with their predominantly Muslims populations. Pakistan accordingly began to court favor with its northern neighbors based on a Shared devotion to political Islam. The doctrines of fundamentalist that Pakistan preached threatened to destabilize long time U.S allies in the Middle East as well as China's predominantly Muslims province of Xingjian.

The arm race between India and Pakistan was exacerbated by resurgence of their long-standing conflict over the predominantly Muslims province Kashmir on India's northern frontier. India blamed Pakistan for supporting the separate agitation against India. The bitter rivalry between these two successor states of the British Raj was reduced all the more threatening to regional security by India's possession of a nuclear capability and Pakistan's ambition to acquire one.

The nuclearization of the Indo-Pakistan region provided a powerful incentive for the two antagonists in the region to seek an improvement in relations to avert a catastrophe. Hopes fordétentearose after Lahore declaration in 1999, but soon it vapors when, in May in same year, Indian army discovered the two thousands armed Muslims guerillas near the village of Kargil in the Indian side of the so called Line of Control, the cease fire line in Kashmir that had been established after the first conflict between the two successor states of British India in 1947-1998 and reaffirmed after the Indo- Pak War of 1971.

The 9/11 event against the United States had powerful repercussion on the South Asia. The Bush Administration enlisted Pakistan as its principal ally in the region during its military operation against Al- Qaeda organization and the Taliban regime in Afghanistan that harbored it. In addition, Mumbai attacks further make the situation more intense and the security environment more vulnerable to more conflicts.

\section{Transnational Challenges in Indo-Pakistan Region: A Historical Overview}

The activities of different criminal organizations across national boundaries and escape the control of government becomes s dilemma for the states. ${ }^{\text {xxix }}$ Consequently, they are much part of international politics. The problems of transnational crimes in South Asia is severe and consists primarily of transnational terrorism, organized crimes, smuggling of arms, trafficking of drugs and people, transnational movements, environment degradation, illegal migration, cyber terrorism and information warfare, diseases and pandemics. All criminal groups and organization takes advantages of corrupt and malfunctioning of politician and as well as of government officials. By doing such criminal activities, these organizations make a lot of profits and undermines the democratic societies of Indo-Pakistan region.

Transnational challenges have been affecting international relations since the time of 1970s conceded intellectually but not practically by the national security framework of states the late 1990s. ${ }^{\mathrm{xl}}$ The 9/11 event and following global war on terror which along terrorism has had to face challenges such as transnational terrorism, organized crimes, smuggling of arms, trafficking of drugs and people, proliferation of weapons of mass destruction and cyber crimes also included brought transnational threats to the vanguard of states security considerations. Transnational issues become more important for the national security performance of Indo-Pakistan region as well as it changed the entire features of the Asian's 
international relations.

Transnational security and security issues have existed for the decades, in Asia and more largely but have increased in add up to, variety, and virulence with the nipping pace of globalization. There is a very crucial point to not that in Indo-Pakistan region, the greatest growth in transnational crimes due to increased in cross-border unlimited movements of people, capitals, and commodities.

There is very important to keep reality about the transmitted of transnational crimes in states. There is a no connection between good governance and fragile states about the transnational issues. ${ }^{\text {xli }}$ Considerably, illegitimate transnational groups and organizations operates among diverse structure of governance, making use of the different opportunities offered by different jurisdiction to accumulate the most effective and money-making operation that transnational networks facilitates.

Globalization proposes terrorist and criminal organization both operate across the borders in more ways that are effective and avail many opportunities to make profit and brutally hit what they oppose. Revolutions in information and technologies make possible for instantaneous transnational networking to secure costless. ${ }^{x \text { lii }}$ This has been a general tendency towards fewer hierarchical, proper, enduring organizations of terrorism and criminal activities.

Globalization also endows with high-level cross-border flows of mass capital and commodities within which terrorist and criminals can concealment their transnational business. ${ }^{\text {xliii }}$ The advancing internationalization of financial and banking system and the arrival of digital money have increased the aptitude of illicit networks to shift and make legal money whereas making it harder for law enforcement agencies to track and control these activities.

The terrorist attacks in Mumbai in 2008 represent the evolving security atmosphere of South Asia. ${ }^{\text {xliv }}$ The strategy of the new wave of terrorism in this region is becoming Post-Westphalian in nature as can be best understood from this transnational operation. They do not respect the borders of the traditional nation-states. The cross-border scope of many of the internal, frequently interrelated, security crises that seriously affected South Asian societies and inter-state relations underscores the importance of developing an effective, broad-based regional response to the threats. Although decorations regarding the need for greater association among states on issues related to border security, mutual legal assistance, and law enforcement, this collaboration has been slow to materialize in South Asia.

There are several basic types of transnational crimes and security threats in South Asia. Most of them have existed in the region for many decades or centuries. Therefore, globalization transformed these transnational crimes with increasing involvement of more people, organizations, and groups having more power, abilities, and capacities to disable the whole societies and government. ${ }^{\text {xlv }}$ Few centuries in the region consider rigid barriers to globalization in order to counter such threats and as a result, both countries confront a new challenge in trying to bring this materialization of globalization's dark dimensions under control. From the last decade of twenty first century trend, it shows that the transnational 
criminal and terrorist groups have the capacity to make less effective South Asia by pulling India and Pakistan into militarized crises.

\section{Conclusion}

Transnational challenges have changed dramatically with the rise of globalization. Radical threats that is not limited to traditional national boundaries because of the new revolution in information technology. New era of globalization offered the new mask for the forces bent on the destruction of the political, social and economic traditional states. Enormous impact of the technological revolution is that criminals invade commercial networks and officials. The activities of several criminal networks across borders and beyond the control of enforcement of the law and government. Therefore, they are all ingredients that domestic politics as international politics.

As globalization and transnationalism are becoming outstanding realities across the global, the researcher of international relations has tries to come up with new issues and problems to analysis of the drawbacks of the globalization and transnationalsim in both North and South poles. This research paper explained the short history dating back to the early civilization of the Indian Subcontinent. This research also discussed the implication of globalization on the cross border relations of states, societies and individuals.

\section{Referrences}

i Sabur, A.(1995). South Asian Security in the Post-Cold War Era: Issues and Outlook. In Iftekharulzzaman. (Ed.), South Asia's Security: Primacy of Internal Dimension. Dhaka: Bangladesh. pp. 1-26.

ii Ibid. p.56.

iii Ahmed, Firdaus. (2003). Limited Nuclear War:Limitless Anxiety. Retrieved June 23, 2012 from http://www.indiatogether.org/2003/mar/fah-limited.htm.

iv Geller, S., \& Singer, J. (1998). Nations At War: A Scientific Study of International Conflict. Cambridge: Cambridge University Press. pp. 23-44.

v Ali, Triq. (2008). The Dual Pakistan: On The Flight Path O f American Power. London: Simon \& Schuster Press. p.23-34.

${ }^{v i}$ Paula, R. (1995). Judging the State: Courts and Constitsutional Conflicts in Pakistan. New York:

Cambridge University Press. pp.34-45.

vii Ibid.

viii Cohen, Stephen P. (1984). The Pakistan Army. Berkeley: University of California Press. pp.134-167.

${ }^{i x}$ Kukreja, Veena. (2003). Contemporary Pakistan: Political Process, Conflicts and Crises. New Delhi: Sage Publications. p.117.

${ }^{\mathrm{x}}$ Ibid. p.86. 
xi Tabb, K., W. (2005). Economic in the Age of Globalization. New York: Colombia University Press. pp.33-88.

xii Waters, M. (1994). Modern Social Theory. London: Sage Publishers. pp-112-232.

xiii Ibid. p.256.

${ }^{\text {xiv }}$ Featherstone, M. (1990). Global Culture. London: Sage Publishers. pp-123-156.

${ }^{x v}$ Foltz, Richard. (1999). Religions of the Silk Road: Overload Trade and Cultural Exchange from Antiquity to the Fifteenth Century. New York: St Martin's Press. pp.34-89.

xvi Ibid. pp.93-111

xvii ibid

${ }^{\text {xviii }}$ Hopkins, A., G. (2003). Globalization in World History. London: Pimlico Publishers. pp.21-143.

xix Ibid. p.150.

${ }^{x x}$ Albrow, M. (1997). The Global Age. Stanford: Stanford University Press. pp.112-145

${ }^{x x i}$ Philip, Cutain, D. (1984). Cross-Cultural Trade in World History. London: Cambridge University Press. pp.13-19.

xxii Michael, P., M. (2003). Development and Social Change: A Global Perspective. New York: Pine Forge Press. pp.44-90.

xxiii Potter, C. (2000). Global Convergence, Divergence, and Development. The Companion to Development Studies.London. Retrieved May 29, 2012, from www.reading.ac.uk/ges/Aboutus/Staff/r-b-potter.aspx.

xxiv Wallerstein, I. (1974). The Rise and Future Demise of the World Capitalist System: concept for Comparative Analysis. pp. 45-78.

xxv Ibid.

xxvi Clark, Ian. (2001). The Post-Cold War Order: The Spoil of Face. New York: Oxford University, Press. pp. 91-104.

xxvii Ibid.

xxviii Ibid. p120.

${ }^{x x i x}$ Appadurai, A. (1996). Modernity at Large: Cultural Dimension of Globalization. Minneapolis: University of Minnesota Press. pp. 74-117.

${ }^{\mathrm{xxx}}$ Ibid. p.132.

xxxi Buzan, M. (1995). The State: the New World Order. New York: Colombia University Press. pp.45-78.

xxxii Ibid. p.83.

xxxiii Posen, Barry. (1994). The Security Dilemma and Ethnic Conflicts. Cambridge: Cambridge University press. pp.15-57.

xxxiv Ali, Muhammad. (1998). The Fearful State: power, people and inrternal War in South Asia. London: Zed Books. pp.33-49. 


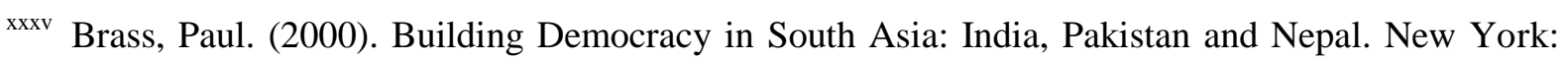
Colombia University Press. pp.23-78.

xxxvi Ibid.

xxxvii Sabur, A.(1995). Op.cit. p. 116.

xxxviii Ibid.

${ }^{\text {xxxix }}$ Peter, M., \& Eduardo, L. (1998). The Locations of Transnationalism. Peter, M., \& Eduardo, L (Edit). Translationalism From Below. Pp.33-45. Retrieved June 23, 2012 from hcd.ucdavis.edu/faculty/.../smith/.../Locations_of_transnationalism.pdf.

${ }^{\mathrm{xl}}$ Ibid.

xli Ludger, pries. (2001). The Approach of Transnational Social Spaces: Responding to New Configuration of the Social Spatial. : New York: Routledge. p.25.

xlii Reuter, P., \& Petrie, C. (Eds). (1999). Transnational Organized Crime. Washington DC: National Academy. Retrieved June 23, 2012 fromhttp://books.nap.edu/openbook.php?isbn=0309065755.

xliii Albrow, M. “(1997). The Global Age. Stanford: Stanford University Press. pp.42-97.

xliv Bhagwati, Jagdish, N. (1998). Op.cit.

${ }^{x l v}$ Swanstrom, Niklas. (2007). The Narcotics Trade: A Threat to Security? National and Transnational Implication. Retrieved September 5, 2012 fromm http:// Global Crimes.com.edu./pdf. 